\title{
Changes in the levels of acute-phase protein and other serum protein fractions in Santa Inês ewes fed with a high-concentrate diet
}

\author{
Annita Morais Girardi ${ }^{\mathrm{a}, *}$, Amanda Festa Sabes ${ }^{\mathrm{a}}$, José Jurandir Fagliari ${ }^{\mathrm{a}}$, Paulo César da Silva ${ }^{\mathrm{a}}$, \\ João Ademir de Oliveira ${ }^{\mathrm{b}}$, Luiz Carlos Marques ${ }^{\mathrm{a}}$ \\ ${ }^{a}$ Departamento de Clínica e Cirurgia Veterinária, Universidade Estadual Paulista (Unesp), Faculdade de Ciências Agrárias e Veterinárias, Via de Acesso Prof. Paulo Donato \\ Castellane, s/n, CEP 14884-900, Jaboticabal, São Paulo, Brazil \\ ${ }^{\mathrm{b}}$ Departamento de Ciências Exatas, Universidade Estadual Paulista (Unesp), Faculdade de Ciências Agrárias e Veterinárias, Via de Acesso Prof. Paulo Donato Castellane, \\ $s / n$, CEP 14884-900, Jaboticabal, São Paulo, Brazil
}

\section{A R T I C L E I N F O}

\section{Keywords:}

Acute-phase proteins

Inflammation

Lipopolysaccharides

Serum globulins

Serum protein electrophoresis

\begin{abstract}
A B S T R A C T
The aim of this study was to evaluate the effects of subacute ruminal acidosis (SARA) on total serum protein (TP), plasma fibrinogen (Fb), and serum protein fractions in seven hay-adapted Santa Inês ewes fed with a highconcentrate diet for 133 days. Blood was extracted, before feeding, by external jugular venipuncture into tubes with ethylenediaminetetraacetic acid dipotassium anticoagulant, to evaluate the $\mathrm{Fb}$ concentration by heat precipitation, and into plain tubes, for TP analysis by the Biuret method and for sodium dodecyl sulfate-polyacrylamide gel electrophoresis (SDS-PAGE). SDS-PAGE obtained the following proteins: immunoglobulin A (IgA) and G (IgG); ceruloplasmin (Cp); transferrin (Tf); albumin; $\alpha_{1}$-antitrypsin ( $\alpha_{1} \mathrm{AT}$ ); haptoglobin (Hp); $\alpha_{1}$-acid glycoprotein ( $\alpha_{1} \mathrm{AG}$ ); and 140, 101, 95, 46, 36, 34, 31, and $23 \mathrm{kDa}$ molecular weight proteins (MWP). Associations among variables and time were evaluated using regression analysis. $\mathrm{Fb}$ concentrations did not change ( $\mathrm{P}>0.05$ ); IgA, $\alpha_{1} \mathrm{AT}$, and Hp levels increased, while $\mathrm{Cp}$ decreased throughout the period. Mean Tf levels increased, reaching the highest value on the 72nd day. The other protein levels oscillated during the study. A positive correlation, measured using Pearson's coefficient, was found between TP and IgG levels ( $r=0.77$; $\mathrm{P}<0.0001)$. IgA, Hp, Tf, and $\alpha 1 \mathrm{AT}$ showed greater potential for use in the diagnosis of SARA. The occurrence of proteins with unknown functions, but that have been highly influenced by the high-grain diet, increases the possibility of identifying inflammatory markers for SARA.
\end{abstract}

\section{Introduction}

The growing sheep meat industry has resulted in increasing numbers of feedlot animals, which are susceptible to disorders such as ruminal acidosis that cause economic problems owing to treatment costs, reduced herd productivity, disposal of animals, and injury. Ruminal acidosis is often categorized into several types including acute and subacute (also called chronic, latent, or subclinical) types (Kleen et al., 2003; Owens et al., 1998).

Subacute ruminal acidosis (SARA) is more common than its acute manifestation, but more difficult to characterize (Cannizzo et al., 2012; Enemark et al., 2002). SARA is defined as an intermittent decrease of ruminal $\mathrm{pH}$ to non-physiological levels after intake of a low-structure, high-energy diet, owing to the inability of a non-adapted ruminal environment to adequately ferment and absorb the resulting short-chain fatty acids (SCFA) (Kleen et al., 2003). However, the rumen microbial population fits diet rich in grains with many amylolytic and lactolytic microorganisms so that the lactic acid does not accumulate (Enemark et al., 2002). The clinical symptoms of SARA appear after a delay from the time of the initial insult (Kleen et al., 2003), manifesting as reduced feed intake and performance; however, animals may not appear to be ill (Owens et al., 1998).

Inflammation due to grain-induced SARA could result from the translocation of lipopolysaccharides (LPS) derived from gram-negative bacteria from the rumen to body circulation (Plaizier et al., 2009; Plaizier et al., 2012). Translocation of LPS may also occur in the large intestine because grain-induced SARA increases its acidity and LPS content; further, the barrier function of the large intestine is more easily compromised than that of the rumen (Dong et al., 2011; Plaizier et al., 2012). LPS interacts with mononuclear, endothelial, and smooth muscle cells; polymorphonuclear granulocytes; and thrombocytes. It also stimulates the production of pro-inflammatory mediators such as

\footnotetext{
* Corresponding author at: Rua Abrahão Diniz, 214, Jardim Marajoara, CEP 14500-000, Ituverava, São Paulo, Brazil.

E-mail addresses: annita.girardi@posgrad.fcav.unesp.br (A.M. Girardi), amanda.sabes@posgrad.fcav.unesp.br (A.F. Sabes), fagliari@fcav.unesp.br (J.J. Fagliari), pcsilva@fcav.unesp.br (P.C.d. Silva), jaoliv@fcav.unesp.br (J.A.d. Oliveira), lmarques@fcav.unesp.br (L.C. Marques).
} 
cytokines (Plaizier et al., 2012). Other immunogenic factors in the digestive tract may contribute to inflammation following ingestion of a high-grain diet (Dong et al., 2011; Plaizier et al., 2009); as SARA can lead to rumenitis, this inflammation could also induce an acute-phase response (APR) (Plaizier et al., 2009; Plaizier et al., 2012).

Acute-phase proteins (APPs) are blood proteins of the innate immune system that change concentration in response to external or internal challenges such as infection, inflammation, surgical trauma, or stress (Eckersall and Bell, 2010; Murata et al., 2004) such as that caused by the transport of ruminants (Giannetto et al., 2011; Piccione et al., 2012). They act as modulators of inflammatory response by interacting with both defensive cells and pathogens (Ceciliani et al., 2012). Because circulating concentrations of APPs reflect disease severity, they may be useful for in vivo disease monitoring (Danscher et al., 2011; Murata et al., 2004), providing an alternative method for assessing disease pathogenesis and monitoring animal health, including diagnosis, prognosis, response to therapy, and welfare status (Ceciliani et al., 2012; Eckersall, 2000; Eckersall and Bell, 2010; Tothova et al., 2014). APPs are non-specific biomarkers (Danscher et al., 2011; Eckersall and Bell, 2010; Tothova et al., 2014) with species-specific responses (Eckersall and Bell, 2010; Murata et al., 2004; Tothova et al., 2014).

APR in ruminants differs significantly from other species, in which haptoglobin (Hp) is a major APP (Eckersall and Bell, 2010). APR in experimental and natural diseases in cattle has been investigated for decades (Ceciliani et al., 2012). Information on APR and the relationships between APP levels and production parameters in sheep is limited (Pfeffer et al., 1993), but Hp and serum amyloid A (SAA) are considered major APPs, $\alpha_{1}$-acid glycoprotein $\left(\alpha_{1} A G\right)$ moderate APP, fibrinogen $(\mathrm{Fb})$ and ceruloplasmin $(\mathrm{Cp})$ minor APPs, and albumin negative APP in this species (Gómez-Laguna et al., 2011). Hp, Cp, and Fb levels may be more useful diagnostic markers than the number of circulating neutrophils in sheep (Pfeffer and Rogers, 1989).

Metabolic disorders in animals may cause activation of the immune system, including initiation of inflammatory responses (Tothova et al., 2014). APPs have been used to investigate the pathophysiology of the gastrointestinal tract in cattle and the effects of diet variation on its function (Ceciliani et al., 2012). Despite recent study with some APPs that indicated that SARA did not stimulate the immune response in dairy cows under field conditions (Cannizzo et al., 2012), they also seem to be informative adjuncts to $\mathrm{pH}$ measurements in ruminal acidosis when other sources of inflammation can be excluded (Danscher et al., 2011) and important in early detection of SARA (Gozho et al., 2006). Thus, the aim of the present study was to evaluate the effects of long-term high-concentrate diet on APPs and other serum protein fractions in Santa Inês sheep.

\section{Materials and methods}

Seven ewes were kept in pens under appropriate hygiene conditions and maintained for 60 days on a basal diet of coast cross hay (Cynodon spp.), drinking water, and mineral mixture (Tortuga Ovinofós com minerais orgânicos, Tortuga Companhia Zootécnica Agrária, São Paulo, Brazil) ad libitum. The basal values were the means of three weekly assessments: 15 days, 7 days, and immediately before (D0) the dietary change. During induction to SARA, based on their average consumption during the basal diet ( $2 \mathrm{~kg}$ organic matter/animal/day), their diet was replaced with $10 \%$ roughage for concentrate feed $(76.8 \%$ ground corn, $18.2 \%$ soybean meal, and 5\% mineral core; Guabi Ruminúcleo Ovinos 40 ADE, Mogiana Alimentos S/A, Campinas, Brazil), daily, up to $80 \%$ concentrate feed (D0-D7). This percentage was maintained until day 133 (D133). No buffer was included in the rations. After changes to the diet were made, measurements were performed daily for the first 14 days (D1-D14), every other day until the 28th day (D16, D18, D20, D22, D24, D26, D28), and weekly for the remainder of the 5-month experiment (D35, D42, D49, D56, D63, D70, D77, D84, D91, D98, D105, D112, D119, D126, D133). Sampling was performed in the morning, prior to feeding.

In order to evaluate the occurrence of SARA, $10-\mathrm{mL}$ ruminal fluid samples were collected through the rumen cannula using a disposable pipette. Each sample was packed in a sterile, $15-\mathrm{mL}$ conical tube and analyzed immediately for the physical characteristics (viscosity, color, odor), sedimentation and flotation test - SFT (seconds; Arcuri et al., 2006), methylene blue reduction time - MBR (seconds; Dirksen et al., 1993), and pH. During spontaneous urination, induced by vulvar massage (Enemark et al., 2002) or by brief restriction of breathing (Benech et al., 2015), urine samples were collected in sterile, 80-mL lidded containers. Urine and ruminal fluid $\mathrm{pH}$ values were immediately measured using a digital pH meter (Digimed DM20, Digicrom Analítica Ltda., São Paulo, Brazil).

From each animal, blood samples were collected by external jugular venipuncture into $10 \mathrm{~mL}$ plastic tubes without anticoagulant (BD Vacutainer, BD Diagnostics - Preanalytical Systems, São Paulo, Brazil), and into $4 \mathrm{~mL}$ tubes with ethylenediaminetetraacetic acid dipotassium anticoagulant $\left(\mathrm{K}_{2}\right.$ EDTA $\left.7.2 \mathrm{mg}\right)$. Blood samples collected into plain tubes were used for serum total protein (TP) and protein electrophoresis analysis. The blood samples collected into tubes with $\mathrm{K}_{2}$ EDTA were used to evaluate the plasma fibrinogen $(\mathrm{Fb})$ concentration. Serum samples were separated quickly by centrifugation at $2500 \mathrm{~g}$ for $10 \mathrm{~min}$ and stored at $-70{ }^{\circ} \mathrm{C}$ for two months before laboratory analysis.

Protein fractionation was performed using sodium dodecyl sulfatepolyacrylamide gel electrophoresis (SDS-PAGE) as described by Laemmli (1970). Protein fraction percentages were measured using a computerized scanning densitometer (Shimadzu CS 9301, Shimadzu Corporation, Tokyo, Japan), with a reference marker solution (SigmaMarker, Sigma-Aldrich Corporation, Saint Louis, Missouri, USA) with molecular weights from 6.5 to $200 \mathrm{kDa}$. Serum protein concentrations $(\mathrm{g} / \mathrm{L})$ were determined by multiplying the percentage of each fraction by the TP concentration obtained by a semi-automatic spectrophotometer (Labquest, Labtest, Brazil) using the Biuret method with a bovine albumin standard $(4 \mathrm{~g} / \mathrm{dL})$ provided with the commercial kit. Fb was determined by heat precipitation (Allison, 2015) and measured using a refractometer (Atago T2-NE Clinical, Atago Co. Ltd., Japan). These analyses were performed at the Research Laboratory of the Department of Veterinary Clinic and Surgery, School of Agrarian and Veterinary Sciences, São Paulo State University, Jaboticabal, Brazil.

Data analysis was performed using commercial statistical software (SAS 9.1, SAS Institute Inc., Cary, North Carolina, USA) to assess associations among variables and time by linear, quadratic, and cubic regressions ( $\mathrm{y}=$ variable value, $\mathrm{x}=$ day after dietary change). Maximum and/or minimum points were obtained by the derivative of the function. Correlation among protein levels was measured using Pearson's coefficient. Score classifications of the correlation between variables were considered weak $(0.01 \leq \mathrm{r} \leq 0.39)$, moderate $(0.40 \leq \mathrm{r} \leq 0.69)$, or strong $(0.70 \leq \mathrm{r} \leq 1.00)$. Statistical significance was set at $\mathrm{P} \leq 0.05$.

This study was approved by the Ethics Commission in Use of Animals of the School of Agrarian and Veterinary Sciences (Protocol no. 008891/12).

\section{Results}

The ruminal fluid remained liquid, sometimes viscous, and its odor changed from characteristic to predominantly acid from the day 4. It remained olive green until the third day, then the yellowish color frequency increased until it predominates from the day 18. The MBR $\left(y=0.00365 x^{2}-0.72524 x+66.81923 ; \quad \mathrm{P} \leq 0.05\right) \quad$ and $\quad$ SFT $(y=-0.32541 x+75.73218 ; \mathrm{P}<0.0001)$ decreased during the observation period. Ruminal $\mathrm{pH}$ decreased until day 20 , increased until day 95, and decreased thereafter $\left(y=-0.00000187 x^{3}+\right.$ $\left.0.00032076 x^{2}-0.01052 x+6.15389 ; \quad \mathrm{P} \leq 0.05\right)$. Urine $\mathrm{pH}$ markedly decreased throughout the study $\left(y=-0.00002244 x^{3}+\right.$ $\left.0.00558 x^{2}-0.33641 x+75.08852 ; \mathrm{P}<0.001\right)$. 
TP levels declined in the first 40 days, then increased $\left(y=-0.00002244 x^{3}+0.00558 x^{2}-0.33641 x+75.08852, \mathrm{P}<0.05\right) . \mathrm{Fb}$ concentrations were not associated with time $(\mathrm{P}>0.05)$.

Sixteen protein fractions were separated using electrophoresis: immunoglobulin A (IgA - $161 \mathrm{kDa}$ ) and G (IgG, the sum of the heavy $52 \mathrm{kDa}$ - and light - $25 \mathrm{kDa}$ - chains), ceruloplasmin ( $\mathrm{Cp}-115 \mathrm{kDa})$, transferrin (Tf $-80 \mathrm{kDa})$, albumin $(64 \mathrm{kDa}), \alpha_{1}$-antitrypsin $\left(\alpha_{1} \mathrm{AT}-\right.$ $58 \mathrm{kDa})$, haptoglobin $(\mathrm{Hp}-42 \mathrm{kDa}), \alpha_{1}$-acid glycoprotein $\left(\alpha_{1} \mathrm{AG}-\right.$ $40 \mathrm{kDa})$, and the $140\left(\mathrm{MWP}_{140}\right), 101\left(\mathrm{MWP}_{101}\right), 95\left(\mathrm{MWP}_{95}\right), 46$ $\left(\mathrm{MWP}_{46}\right), 36\left(\mathrm{MWP}_{36}\right), 34\left(\mathrm{MWP}_{34}\right), 31\left(\mathrm{MWP}_{31}\right)$, and $23\left(\mathrm{MWP}_{23}\right) \mathrm{kDa}$ molecular weight proteins.

Mean $\mathrm{MWP}_{95}$ levels increased slightly until the maximum point on day 72, but remained almost constant $\left(y=-0.00337 x^{2}+\right.$ $0.48444 x+9.63465, \mathrm{P} \leq 0.05)$.

IgA $\left(y=0.0000501 x^{3}-0.01077 x^{2}+0.76237 x+21.57467, \mathrm{P} \leq 0.05\right)$ and $\alpha_{1}$ AT $\left(y=-0.00964 x^{2}+1.94832 x+220.84517, \mathrm{P}<0.01\right)$ levels tended to increase throughout the study period, with maximum values at days 64 and 101, respectively. IgG levels decreased until day 65, then returned to baseline later $\left(y=0.17194 x^{2}+22.51146 x+2423.2269\right.$, $\mathrm{P}<0.0001)$. $\mathrm{MWP}_{23}$ concentrations increased from days 13 to 110 $\left(y=-0.00017756 x^{3}+0.03288 x^{2}-0.76653 x+151.51276, \mathrm{P}<0.0001\right)$. Hp levels increased $(y=0.06242 x+7.77903, \mathrm{P}<0.0001)$, while $\mathrm{Cp}$ decreased throughout the study period $(y=-0.2865 x+100.36258$, $\mathrm{P}<0.0001) . \quad \mathrm{MWP}_{140} \quad\left(y=0.00004084 x^{3}-0.00876 x^{2}+0.44361 x+\right.$ $15.53768)$ and $\mathrm{MWP}_{101} \quad\left(y=0.00007348 x^{3}-0.01451 x^{2}+0.7273 x+\right.$ 24.09274) concentrations increased until days 33 and 34, respectively, and then declined to their minimum values at days 110 and 98 , respectively $(\mathrm{P}<0.001)$. $\mathrm{MWP}_{34}$ levels decreased until day 4 , and then increased up to day $121\left(y=-0.00003578 x^{3}+0.00873 x^{2}-0.53909 x+\right.$ 48.90945, $\mathrm{P} \leq 0.05$ ). Mean Tf increased until day 72, and then tended to return to baseline values $\left(y=-0.06715 x^{2}+9.6328 x+391.23305\right.$, $\mathrm{P}<0.0001$ ). Albumin concentrations were almost constant, with a slight decrease until day $52\left(y=0.05417 x^{2}-5.6300 x+3868.23207\right.$, $\mathrm{P}<0.01$ ). $\mathrm{MWP}_{46}$ levels decreased until day 55, then increased to above baseline values by the end of the observation period $\left(y=0.00569 x^{2}-0.62371 x+50.43648, \mathrm{P}<0.0001\right)$. $\alpha_{1}$ AG concentrations fell slightly in the first 32 days $\left(y=-0.00001301 x^{3}+\right.$ $\left.0.00255 x^{2}-0.12424 x+11.615, \mathrm{P}<0.05\right) . \mathrm{MWP}_{36}$ means decreased prior to day 23, increased until day 93, then declined $\left(y=-0.00015478 x^{3}+0.02673 x^{2}-0.97088 x+26.1451, \quad \mathrm{P}<0.01\right)$. $\mathrm{MWP}_{31}$ levels decreased in the first 49 days, before increasing again $\left(y=0.00214 x^{2}-0.21084 x+48.23116, \mathrm{P}<0.001\right)$.

The correlation between TP and IgG levels was strong $(r=0.77$; $\mathrm{P}<0.0001$ ), while correlations between the levels of TP and albumin $(\mathrm{r}=0.54), \mathrm{Cp}$ and $\mathrm{MWP}_{140}(\mathrm{r}=0.47), \mathrm{Cp}$ and $\alpha_{1} \mathrm{AT}(\mathrm{r}=-0.54)$, Tf and $\mathrm{MWP}_{95}(\mathrm{r}=0.51)$, Tf and $\alpha_{1} \mathrm{AT}(\mathrm{r}=0.44)$, Tf and $\mathrm{MWP}_{23}$ $(\mathrm{r}=0.42)$, and $\alpha_{1} \mathrm{AT}$ and $\mathrm{MWP}_{23} \quad(\mathrm{r}=0.58)$ were moderate $(\mathrm{P}<0.0001)$. The other correlations were weak or statistically insignificant.

\section{Discussion}

The results obtained in ruminal fluid and urine confirm that sheep had SARA during the study. As observed in cows with SARA (Enemark et al., 2002), the physical features of ruminal fluid during most of the period and the decrease of MBR and SFT due to greater ruminal microbiota metabolism are indicative of ruminal acidosis (Feitosa, 2008; Jones and Smith, 2009). After the initial reduction of ruminal pH, similar to dairy cattle induced to SARA (Steele et al., 2011), this variable showed fluctuation, possibly because the long-term, high-grain diet increased $\mathrm{HCO}_{3}{ }^{-}$secretion into the reticulo-rumen (Gäbel et al., 1991), and propionate, butyrate, and lactate absorption in the rumen (Schwaiger et al., 2013). The decrease of urine $\mathrm{pH}$, as observed in sheep fed $70 \%$ concentrate feed (Minervino et al., 2014), indicates regulation of metabolic acidosis caused by SARA, since the small lung capacity of ruminants requires acid elimination via the kidneys (Enemark et al.,
2002), and renal $\mathrm{HCO}_{3}{ }^{-}$retention and acid excretion are necessary for long-term correction of metabolic acidosis (Houpt, 2006; Carlson, 2009; Jones, 2010). The ruminal pH above SARA limits (Owens et al., 1998; Enemark et al., 2002; Kleen et al., 2003) does not exclude its occurrence, because further parameters are required to diagnose it (Brossard et al., 2003), as exemplified by ruminal fluid characteristics and urinary pH. Moreover, ruminal pH oscillates in SARA (Espinasse et al., 1995; Kleen et al., 2003), then the daily punctual evaluation prior to feeding could not demonstrate lower values that certainly occurred during the day.

Previous studies using SDS-PAGE showed different numbers of protein fractions in other diseases in sheep (Chaves et al., 2011; Costa et al., 2010; Pereira et al., 2009), but their main APPs were similar to those described in this current study.

Correlations among proteins differed from those reported previously for sheep (Costa et al., 2010; Pfeffer et al., 1993), possibly because other disorders result in different changes in APPs profiles. The correlation analysis showed that TP levels changed in response to IgG and albumin concentrations, which can be observed in the initial decrease of TP that, as described by Rodríguez-Lecompte et al. (2014) in cows with SARA, was due to reduction of serum albumin and gamma globulins. This reduction differs from small ruminants with acute ruminal acidosis (Patra et al., 1996; Vieira et al., 2012; Zein-Eldin et al., 2014).

Albumin levels decreased slightly until day 52, similar to other induced inflammatory disorders in sheep (Costa et al., 2010; Pfeffer et al., 1993) and goats (González et al., 2008). During the APR, the increased demand for amino acids for synthesis of positive APPs reduces the hepatic formation of albumin (Tothova et al., 2014), which is consistent with the present results.

The forestomach epithelia comprise a large surface continuously exposed to microbes (Ceciliani et al., 2012), and some of the proteins seem to play a role in the protection of the gastrointestinal tract from increased susceptibility to infection during acidosis. Increasing levels of IgA throughout the study are similar to observations of Costa et al. (2010), who suggested that this rise may occur in response to the requirement for protection of body surfaces against infection. Similarly, the initial decrease in IgG levels may be due to its migration to control infections (Costa et al., 2010). Furthermore, the increase in Tf concentration until day 72 can be explained by its assistance to the host's non-specific defenses against microbial challenge (Murata et al., 2004).

Some APPs appeared to play a role in the control of inflammation during SARA. The initial decrease of $\alpha_{1} \mathrm{AG}$ was similar to sheep intoxicated by Ipomoea asarifolia (Chaves et al., 2011), and its subsequent increase can be attributed to its powerful anti-inflammatory effect (Ceciliani et al., 2012; Hochepied et al., 2003). Therefore, despite the slight oscillation during the study, $\alpha_{1}$ AG can be a useful marker for chronic conditions in sheep (Eckersall et al., 2007). In the same way, the increase in $\alpha_{1} \mathrm{AT}$ levels, which limits tissue injury at the site of inflammation by inhibiting proteases (Tothova et al., 2014), could indicate that $\alpha_{1}$ AT participates in ruminal adaptation to the high-concentrate diet.

The upward trend of Hp levels was previously reported in ruminal acidosis induced by high-concentrate diets (Danscher et al., 2011; González et al., 2010; Gozho et al., 2005; Gozho et al., 2006; Huo et al., 2013; Khafipour et al., 2009; Mohebbi et al., 2010; Rodríguez-Lecompte et al., 2014), which is possibly due to the acidic rumen environment (Danscher et al., 2011; Mohebbi et al., 2010), release of LPS in the rumen, and its translocation into the peripheral circulation (Gozho et al., 2005; Khafipour et al., 2009). As described for goats (González et al., 2010), serum Hp level seems to be a potential indicator of ruminal acidosis for sheep.

The constant $\mathrm{Fb}$ concentration was consistent with the findings of studies regarding ruminal acidosis induced by sucrose (RodríguezLecompte et al., 2014) or high-grain diets (González et al., 2010; Gozho et al., 2007; Li et al., 2012; Mohebbi et al., 2010). Although Fb has been shown to be a useful APP in other ruminant diseases (Costa et al., 2010; 
Danscher et al., 2011; González et al., 2008; Pfeffer and Rogers, 1989; Pfeffer et al., 1993), this was not observed in relation to SARA.

The $\mathrm{Cp}$ concentration decreased during the study, contrary to a report that its level was not affected by high-grain ration in lambs (Mohebbi et al., 2010). Compared to the other APPs, Cp did not seem to be a good indicator of SARA in sheep.

$\mathrm{MWP}_{140}, \mathrm{MWP}_{101}, \mathrm{MWP}_{95}, \mathrm{MWP}_{46}, \mathrm{MWP}_{36}, \mathrm{MWP}_{34}, \mathrm{MWP}_{31}$, and $\mathrm{MWP}_{23}$ proteins are not described in literature, and their functions remain unknown; however, several of them, $\mathrm{MWP}_{140}, \mathrm{MWP}_{101}, \mathrm{MWP}_{46}$, and $\mathrm{MWP}_{23}$, showed great oscillations during the experimental period. This is interesting because the introduction of new APPs and their mediators to veterinary science can accelerate the understanding of innate immune mechanisms and pathophysiology of infection and inflammation in animals (Murata et al., 2004).

Despite reports that APPs are inadequate to detect chronic disease (Pfeffer et al., 1993), and that APR in grain-induced SARA did not progress into acute inflammation (Li et al., 2012), our results showed significant variations of serum protein fractions in sheep fed a highgrain diet for a long period. These findings are consistent with the suggestion by Ceciliani et al. (2012) that the APR should be more properly defined as "systemic reaction to inflammation" because it may accompany both acute and chronic inflammation.

\section{Conclusion}

Long-term ingestion of a high-concentrate diet induced changes in serum protein profile of sheep. Among the proteins identified, IgA, Hp, Tf, and $\alpha 1 \mathrm{AT}$ showed greater potential for use in the diagnosis of SARA. The occurrence of proteins with unknown functions, but that have been highly influenced by the high-grain diet, increases the possibility of identifying inflammatory markers for SARA.

\section{Conflict of interest statement}

Authors declare that there is no conflict of interests regarding the publication of this paper.

\section{Authors' contributions}

A.M.G. participated in the study design, carried out the experiment and drafted the manuscript. A.F.S. participated in the research conduction and laboratory tests. J.J.F. helped in the analysis and interpretation of electrophoretic tracings. P.C.S. helped and coordinated the electrophoresis analysis. J.A.O. participated in the design of the study and performed the statistical analysis. L.C.M. conceived of the study, and participated in its design and coordination and helped to draft the manuscript.

\section{Acknowledgement}

This work was funded by grants \#2012/09111-7 and \#2012/ 09220-0 from the São Paulo Research Foundation (FAPESP).

\section{References}

Allison, R.W., 2015. Avaliação laboratorial das proteínas do plasma e do soro sanguíneo. In: Thrall, M.A., Weiser, G., Allison, R.W., Campbell, T.W. (Eds.), Hematologia e Bioquímica Clínica Veterinária, second ed. Roca, São Paulo, pp. 398-411.

Arcuri, P.B., Lopes, F.C.F., Carneiro, J.C., 2006. Microbiologia do rumen. In: Berchielli, T.T., Pires, A.V., Oliveira, S.G. (Eds.), Nutrição de Ruminantes. Funep, Jaboticabal, pp. 183-228.

Benech, A., Cal-Pereyra, L., Da Silva, S., Acosta-Dibarrat, J., González-Montaña, J.R. 2015. Transient apnoea in sheep: an alternative method for serial urine sample collection. Vet. Arh. 85 (3), 293-307(Available from: < http://www-staro.vef.unizg.hr/ vetarhiv/papers/2015-85-3-6.pdf > . Accessed: 15 February 2018).

Brossard, L., Martin, C., Michalet-Doreau, B., 2003. Ruminal fermentative parameters and blood acid-basic balance changes during the onset and recovery of induced latent acidosis in sheep. Anim. Res. 52 (6), 513-530. http://dx.doi.org/10.1051/ animres:2003036. (Available from: < https://doi.org/10.1051/animres:2003036 > .
Accessed: 15 February 2018).

Cannizzo, C., Gianesella, M., Giudice, E., Messina, V., Piccione, G., Morgante, M., 2012 Serum acute phase proteins in cows with SARA (Subacute Ruminal Acidosis) suspect. Arq. Bras. Med. Vet. Zootec. 64 (1), 15-22. http://dx.doi.org/10.1590/S0102 09352012000100003. (Available from: < https://doi.org/10.1590/S0102 $09352012000100003>$. Accessed: 15 February 2018).

Carlson, G.P., 2009. Clinical chemistry tests. In: Smith, B.P. (Ed.), Large Animal Internal Medicine, fourth ed. Mosby Elsevier, Saint Louis, pp. 375-435.

Ceciliani, F., Ceron, J.J., Eckersall, P.D., Sauerwein, H., 2012. Acute phase proteins in ruminants. J. Proteomics 75 (14), 4207-4231. http://dx.doi.org/10.1016/j.jprot. 2012.04.004.(Available from: < https://doi.org/10.1016/j.jprot.2012.04.004 > . Accessed: 15 February 2018).

Chaves, D.P., Fagliari, J.J., Silva, P.C., 2011. Proteinograma sérico de ovinos intoxicados experimentalmente por salsa. Ciênc. Anim. Bras. 12 (3), 547-553. http://dx.doi.org/ 10.5216/cab.v12i3.9840.(Available from: < https://www.revistas.ufg.br/vet/ article/view/9840 > . Accessed: 15 February 2018).

Costa, N.A., Simão, L.C.V., Santos, R.A., Afonso, J.A.B., Fagliari, J.J., Cardoso, E.C., Soares, P.C., Mendonça, C.L., 2010. Proteinograma e teores de cobre, ferro e zinco no soro sanguíneo de ovelhas da raça Santa Inês com mastite experimental por Staphylococcus aureus. Pesqui. Vet. Bras. 30 (5), 435-442. http://dx.doi.org/10.1590/ S0100-736X2010000500011.(Available from: < https://doi.org/10.1590/S0100736X2010000500011 > . Accessed: 15 February 2018).

Danscher, A.M., Thoefner, M.B., Heegaard, P.M.H., Ekstrøm, C.T., Jacobsen, S., 2011. Acute phase protein response during acute ruminal acidosis in cattle. Livest. Sci. 135 (1), 62-69. http://dx.doi.org/10.1016/j.livsci.2010.06.009.(Available from: < http://www.sciencedirect.com/science/article/pii/ S1871141310002210 > . Accessed: 15 February 2018).

Dirksen, G., Gründer, H.D., Stöber, M., 1993. Rosenberger: exame clínico de bovinos, third ed. Guanabara Koogan, Rio de Janeiro.

Dong, G., Liu, S., Wu, Y., Lei, C., Zhou, J., Zhang, S., 2011. Diet-induced bacterial immunogens in the gastrointestinal tract of dairy cows: impacts on immunity and metabolism. Acta Vet. Scand. 53, 48. http://dx.doi.org/10.1186/1751-0147-53-48. (Available from: < https://actavetscand.biomedcentral.com/articles/10.1186/17510147-53-48 > . Accessed: 15 February 2018).

Eckersall, P.D., Bell, R., 2010. Acute phase proteins: biomarkers of infection and inflammation in veterinary medicine. Vet. J. 185 (1), 23-27. http://dx.doi.org/10. 1016/j.tvjl.2010.04.009.(Available from: < https://doi.org/10.1016/j.tvjl.2010.04. 009 > . Accessed: 15 February 2018).

Eckersall, P.D., Lawson, F.P., Bence, L., Waterston, M.M., Lang, T.L., Donachie, W., Fontaine, M.C., 2007. Acute phase protein response in an experimental model of ovine caseous lymphadenitis. BMC Vet. Res. 3, 35. http://dx.doi.org/10.1186/17466148-3-35.(Available from: < https://bmcvetres.biomedcentral.com/articles/10. 1186/1746-6148-3-35 > . Accessed: 15 February 2018).

Eckersall, P.D., 2000. Recent advances and future prospects for the use of acute phase proteins as markers of disease in animals. Rev. Med. Vet. 151 (7), 577-584(Available from: < http://www.revmedvet.com/2000/RMV151_577_584.pdf > . Accessed: 15 February 2018).

Enemark, J.M.D., Jorgensen, R.J., Enemark, P.S., 2002. Rumen acidosis with special emphasis on diagnostic aspects of subclinical rumen acidosis: a review. Vet. Med. Zoot. 20 (42), 16-29(Available from: < http://vetzoo.lsmuni.lt/data/vols/2002/20/ pdf/enemark.pdf > . Accessed: 15 February 2018).

Espinasse, J., Kuiper, R., Schelcher, F., 1995. Physiopathologie du complexe gastrique. In: Jarrige, R., Ruckebusch, Y., Demarquilly, C., Farce, M.H., Journet, M. (Eds.), Nutrition des Ruminants Domestiques: ingestion et digestion. INRA Editions, Versailles, pp. 805-852.

Feitosa, F.L.F., 2008. Exame físico geral ou de rotina. In: Feitosa, F.L.F. (Ed.), Semiologia Veterinária: a arte do diagnóstico, second ed. Roca, São Paulo, pp. 77-102.

Gäbel, G., Bestmann, M., Martens, H., 1991. Influences of diet, short-chain fatty acids, lactate and chloride on bicarbonate movement across the reticulorumen wall of sheep. J. Vet. Med. A 38 (7), 523-529. http://dx.doi.org/10.1111/j.1439-0442.1991. tb01043.x.(Available from: < https://doi.org/10.1111/j.1439-0442.1991.tb01043. $x>$. Accessed: 15 February 2018).

Gómez-Laguna, J., Salguero, F.J., Pallarés, F.J., Rodríguez-Gómez, I.M., Barranco, I., Carrasco, L., 2011. Acute phase proteins as biomarkers in animal health and welfare. In: Veas, F. (Ed.), Acute Phase Proteins as Early Non-specific Biomarkers of Human and Veterinary Diseases. Intech, Rijeka, pp. 259-298. http://dx.doi.org/10.5772/ 19166.(Available from: < https://doi.org/.\%20http://dx.doi.org/\%2010.5772/ $19166>$. Accessed: 15 February 2018).

Giannetto, C., Fazio, F., Casella, S., Marafioti, S., Giudice, E., Piccione, G., 2011. Acute phase protein response during road transportation and lairage at a slaugtherhouse in feedlot beef cattle. J. Vet. Med. Sci. 73 (11), 1531-1534. http://dx.doi.org/10.1292/ jvms.11-0157.(Available from: < https://doi.org/10.1292/jvms.11-0157 > . Accessed: 15 February 2018).

González, F.H.D., Tecles, F., Martinez-Subiela, S., Tvarijonaviciute, A., Vasco, L.S., Cerón, J.J., 2008. Acute phase protein responses in goats. J. Vet. Diagn. Invest. 20 (5), 45-49. http://dx.doi.org/10.1177/104063870802000507. (Available from: < http://journals.sagepub.com/doi/10.1177/104063870802000507 > Accessed: 15 February 2018).

González, F.H.D., Ruipérez, F.H., Sánchez, J.M., Souza, J.C., Martinez-Subiela, S., Cerón, J.J., 2010. Haptoglobin and serum amyloid A in subacute ruminal acidosis in goats. Rev. Med. Vet. Zoot. 57, 159-167(Available from: < http://www.scielo.org.co/pdf/ rfmvz/v57n3/v57n3a01.pdf > . Accessed: 15 February 2018).

Gozho, G.N., Plaizier, J.C., Krause, D.O., Kennedy, A.D., Wittenberg, K.M., 2005. Subacute ruminal acidosis induces ruminal lipopolysaccharide endotoxin release and triggers an inflammation response. J. Dairy Sci. 88 (4), 1399-1403. http://dx.doi. org/10.3168/jds.S0022-0302(05)72807-1.. Available from: < https://doi.org/10. 
3168/jds.S0022-0302(05)72807-1 > . Accessed: 15 February 2018

Gozho, G.N., Krause, D.O., Plaizier, J.C., 2006. Rumen lipopolysaccharide and inflammation during grain adaptation and subacute ruminal acidosis in steers. J. Dairy Sci. 89 (11), 4404-4413. http://dx.doi.org/10.3168/jds.S0022-0302(06)72487-0.. Available from: < https://doi.org/10.3168/jds.S0022-0302(06)72487-0 > . Accessed: 15 February 2018.

Gozho, G.N., Krause, D.O., Plaizier, J.C., 2007. Ruminal lipopolysaccharide concentration and inflammatory response during grain-induced subacute ruminal acidosis in dairy cows. J. Dairy Sci. 90 (2), 856-866. http://dx.doi.org/10.3168/jds.S0022-0302(07) 71569-2.. Available from: < https://doi.org/10.3168/jds.S0022-0302(07)71569$2>$. Accessed: 15 February 2018.

Hochepied, T., Berger, F.G., Baumann, H., Libert, C., 2003. Alpha(1)-acid glycoprotein: an acute phase protein with inflammatory and immunomodulating properties. Cytokine Growth Factor Rev. 14 (1), 25-34. http://dx.doi.org/10.1016/S1359-6101(02) 00054-0.. Available from: < https://doi.org/10.1016/S1359-6101(02)00054-0 > . Accessed: 15 February 2018.

Houpt, T.R., 2006. Equilíbrio ácido-básico. In: Reece, W.O. (Ed.), Dukes - Fisiologia dos Animais Domésticos, twelfth ed. Guanabara Koogan, Rio de Janeiro, pp. 147-160.

Huo, W., Zhu, W., Mao, S., 2013. Effects of feeding increasing proportions of corn grain on concentration of lipopolysaccharide in the rumen fluid and the subsequent alterations in immune responses in goats. Asian-Australas. J. Anim. Sci. 26 (10), 1437-1445. http://dx.doi.org/10.5713/ajas.2013.13143. (Available from: < https:// www.ajas.info/upload/pdf/ajas-26-10-1437-10.pdf > . Accessed: 15 February 2018).

Jones, S.L., Smith, B.P., 2009. Diseases of alimentary tract. In: Smith, B.P. (Ed.), Large Animal Internal Medicine, fourth ed. Mosby Elsevier, Saint Louis, pp. 667-892.

Jones, M.B., 2010. Basic interpretation of metabolic acidosis. Crit. Care Nurse 30 (5), 63-69. http://dx.doi.org/10.4037/ccn2010521. (Available from: < http://ccn. aacnjournals.org/content/30/5/63 > . Accessed: 15 February 2018).

Khafipour, E., Krause, D.O., Plaizier, J.C.A., 2009. A grain-based subacute ruminal acidosis challenge causes translocation of lipopolysaccharide and triggers inflammation. J. Dairy Sci. 92 (3), 1060-1070. http://dx.doi.org/10.3168/jds.2008 1389.(Available from: < https://doi.org/10.3168/jds.2008-1389 > . Accessed: 15 February 2018).

Kleen, J.L., Hooijer, G.A., Rehage, J., Noordhuizen, J.P.T.M., 2003. Subacute ruminal acidosis (SARA): a review. J. Vet. Med. A 50 (8), 406-414. http://dx.doi.org/10 1046/j.1439-0442.2003.00569.x.(Available from: < https://doi.org/10.1046/j. 1439-0442.2003.00569.x > . Accessed: 15 February 2018)

Laemmli, U., 1970. Cleavage of structural proteins during the assembly of the head of bacteriophage T4. Nature 227, 680-685. http://dx.doi.org/10.1038/227680a0. (Available from: < https://doi.org/10.1038/227680a0 > . Accessed: 15 February 2018)

Li, S., Gozho, G.N., Gakhar, N., Khafipour, E., Krause, D.O., Plaizier, J.C., 2012. Evaluation of diagnostic measures for subacute ruminal acidosis in dairy cows. Can. J. Anim. Sci. 92 (3), 353-364. http://dx.doi.org/10.4141/cjas2012-004.(Available from: < https://doi.org/10.4141/cjas2012-004 > . Accessed: 15 February 2018).

Minervino, A.H.H., Araújo, C.A.S.C., Kaminishikawahara, C.M., Soares, F.B., Rodrigues, F.A.M.L., Reis, L.F., Oliveira, F.L.C., Barrêto Júnior, R.A., Mori, C.S., Ortolani, E.L., 2014. Influência de diferentes dietas com alto teor de concentrados sobre parâmetros ruminais, bioquímicos e urinários de ovinos. Braz. J. Vet. Res. Anim. Sci. 51 (1), 30-36. http://dx.doi.org/10.11606/issn.1678-4456.v51i1p30-36.(Available from: < https://doi.org/10.11606/issn.1678-4456.v51i1p30-36 > . Accessed: 15 February 2018)

Mohebbi, M., Sajedianfard, J., Nazifi, S., Samimi, A.S., 2010. Changes of serum amyloid A, haptoglobin, ceruloplasmin, fibrinogen, and lipid-associated sialic acid in sheep fed high grain rations with altered digestive functions. Comp. Clin. Pathol. 19 (6), 541-546. http://dx.doi.org/10.1007/s00580-009-0918-4.(Available from: < https://doi.org/10.1007/s00580-009-0918-4 > . Accessed: 15 February 2018).

Murata, H., Shimada, N., Yoshioka, M., 2004. Current research on acute phase proteins in veterinary diagnosis: an overview. Vet. J. 168 (1), 28-40. http://dx.doi.org/10. 1016/S1090-0233(03)00119-9.. Available from: < https://doi.org/10.1016/S10900233(03)00119-9 > . Accessed: 15 February 2018

Owens, F.N., Secrist, D.S., Hill, W.J., Gill, D.R., 1998. Acidosis in cattle: a review. J. Anim. Sci. 76 (1), 275-286. http://dx.doi.org/10.2527/1998.761275x.(Available from: < https://doi.org/10.2527/1998.761275x > . Accessed: 15 February 2018).

Patra, R.C., Lal, S.B., Swarup, D., 1996. Biochemical profile of rumen liquor, blood and urine in experimental acidosis in sheep. Small Rumin. Res. 19 (2), 177-180. http:// dx.doi.org/10.1016/0921-4488(95)00743-1.. Available from: < https://dx.doi.org/ 10.1016/0921-4488(95)00743-1 > . Accessed: 15 February 2018.

Pereira, W.A.B., Faria, J.L.M., Silva, P.C., Hatayde, M.R., Fagliari, J.J., 2009. Proteinograma sérico de ovinos intoxicados por cobre. Ciênc. Anim. Bras. 1, 354-359(Available from: < https://www.revistas.ufg.br/vet/article/view/7800/ $5591>$. Accessed: 15 February 2018).

Pfeffer, A., Rogers, K.M., 1989. Acute phase response of sheep: changes in the concentrations of ceruloplasmin, fibrinogen, haptoglobin and the major blood cell types associated with pulmonar damage. Res. Vet. Sci. 46 (1), 118-124(Available from: < https://www.ncbi.nlm.nih.gov/pubmed/2466310 > . Accessed: 15 February 2018).

Pfeffer, A., Rogers, K.M., O’Keeffe, L., Osborn, P.J., 1993. Acute phase protein response, food intake, liveweight change and lesions following intrathoracic injection of yeast in sheep. Res. Vet. Sci. 55 (3), 360-366. http://dx.doi.org/10.1016/0034-5288(93) 90108-R.. Available from: < https://dx.doi.org/10.1016/0034-5288(93)90108$\mathrm{R}>$. Accessed: 15 February 2018.

Piccione, G., Casella, S., Giannetto, C., Giudice, E., Fazio, F., 2012. Utility of acute phase proteins as biomarkers of transport stress in ewes. Small Rumin. Res. 107 (2-3), 167-171. http://dx.doi.org/10.1016/j.smallrumres.2012.05.008. (Available from: < https://doi.org/10.1016/j.smallrumres.2012.05.008 > . Accessed: 15 February 2018)

Plaizier, J.C., Krause, D.O., Gozho, G.N., McBride, B.W., 2009. Subacute ruminal acidosis in dairy cows: the physiological causes, incidence and consequences. Vet. J. 176 (1), 21-31. http://dx.doi.org/10.1016/j.tvjl.2007.12.016.(Available from: < https://doi. org/10.1016/j.tvjl.2007.12.016 > . Accessed: 15 February 2018).

Plaizier, J.C., Khafipour, E., Li, S., Gozho, G.N., Krause, D.O., 2012. Subacute ruminal acidosis (SARA), endotoxins and health consequences. Anim. Feed Sci. Technol. 172 (1-2), 9-21. http://dx.doi.org/10.1016/j.anifeedsci.2011.12.004.(Available from: < https://doi.org/10.1016/j.anifeedsci.2011.12.004 > . Accessed: 15 February 2018).

Rodríguez-Lecompte, J.C., Kroeker, A.D., Ceballos-Márquez, A., Li, S., Plaizier, J.C. Gomez, D.E., 2014. Evaluation of the systemic innate immune response and metabolic alterations of nonlactating cows with diet-induced subacute ruminal acidosis. J. Dairy Sci. 97 (12), 7777-7787. http://dx.doi.org/10.3168/jds.2014-8319.(Available from: < https://doi.org/10.3168/jds.2014-8319 > . Accessed: 15 February 2018).

Schwaiger, T., Beauchemin, K.A., Penner, G.B., 2013. Duration of time that beef cattle are fed a high-grain diet affects the recovery from a bout of ruminal acidosis: short-chain fatty acid and lactate absorption, saliva production, and blood metabolites. J. Anim. Sci. 91 (12), 5743-5753. http://dx.doi.org/10.2527/jas.2013-6472.(Available from: < https://dx.doi.org/10.2527/jas.2013-6472 > . Accessed: 15 February 2018)

Steele, M.A., Croom, J., Kahler, M., Alzahal, O., Hook, S.E., Plaizier, K., Mcbride, B.W., 2011. Bovine rumen epithelium undergoes rapid structural adaptations during graininduced subacute ruminal acidosis. Am. J. Physiol. Regul. Integr. Comp. Physiol. 300 (6), R151-R1523. http://dx.doi.org/10.1152/ajpregu.00120.2010.(Available from: < https://doi.org/10.1152/ajpregu.00120.2010 > . Accessed: 15 February 2018).

Tothova, C., Nagy, O., Kovac, G., 2014. Acute phase proteins and their use in the diagnosis of diseases in ruminants: a review. Vet. Med. 59 (4), 163-180(Available from: < http://vri.cz/docs/vetmed/59-4-163.pdf > . Accessed: 15 February 2018).

Vieira, A.C., Câmara, A.C., Mendonça, C.L., Afonso, A.B., 2012. Perfil hematológico e bioquímico de ovinos suplementados com salinomicina submetidos à acidose láctica ruminal. Ciênc. Anim. Bras. 13 (2), 259-271. http://dx.doi.org/10.5216/cab.v13i2. 17263.(Available from: < https://doi.org/10.5216/cab.v13i2.17263 > . Accessed: 15 February 2018).

Zein-Eldin, M.M., Ghanem, M.M., Abd El-Raof, Y.M., El-Attar, H.M., El-Khaiat, H.M., 2014. Clinical, haematobiochemical and ruminal changes during the onset and recovery of induced lactic acidosis in sheep. Biotechnol. Anim. Husb. 30 (4), 647-659. http://dx.doi.org/10.2298/BAH1404647Z. (Available from: < http://www. doiserbia.nb.rs/img/doi/1450-9156/2014/1450-91561404647Z.pdf > . Accessed: 15 February 2018) 